\title{
Role of hydroxy trace minerals on health and production of livestock: a review
}

\author{
B.V.V. Reddy ${ }^{1 *}$, S. Nayak ${ }^{1}$, A. Khare ${ }^{1}$, R. P. Pal ${ }^{2}$, R. Sharma ${ }^{1}$, A. \\ Chourasiya $^{1}$, S. Namdeo ${ }^{3}$, S. Thakur $^{1}$
}

${ }^{1}$ Depatment of Animal Nutrition, NDVSU, Jabalpur-482001, Madhya Pradesh; ${ }^{2}$ Animal Science, PAU, Ludhiana141004, Punjab; ${ }^{3}$ Department of Animal Nutrition, LUVAS, Hissar-125011, Haryana, India;

*Corresponding authorE-mail- vedha.bunny@ gmail.com; mob no- 7901001196

Journal of Livestock Scienc (ISSN online 2277-6214) 12: 279-286

Received on 10/7/21, Accepted on 3/9/21, Published on 12/9/21

doi.10.33259/JLivestSci.2021.279-286

\begin{abstract}
Trace minerals are micro nutrients that are required in less amount $(<100 \mathrm{ppm})$, but are required for maintaining health, production and reproduction of living organisms. Feed ingredients generally used in diets of animals may contain improper concentrations of essential trace minerals (TM) and may also contain higher concentrations of TM antagonists. So, it is necessary for supplementation of TM in ration of animals. Though, trace minerals have conventionally been supplemented in animal diets as inorganic salts (primarily sulfate and oxide forms), organic trace minerals (chelated or complexed to organic ligands) and nano form. However, there are some negative aspects with respect to these forms of minerals. Hydroxy form represents a new group of trace mineral source that include copper, zinc and manganese. They are non-hygroscopic, free of dust, non-oxidative and are insoluble in the rumen due to presence of covalent bond in its crystalline structure. Recently some works have been conducted and have shown the positive impact of hydroxy mineral in animal feed i.e. better stability of feed components as well as in animals' i.e. higher bioavailability as compared with other form of trace minerals. This review summarises the information currently available on hydroxy form of trace minerals, including supporting research conducted in livestock including poultry, with particular focus on the impact of this hydroxy form on health and production of animals.
\end{abstract}

Keywords: Trace minerals, hydroxy form, bioavailability, stability 
Reddy et al 2021/ J Livestock Sci. 12: 279-286

\section{Introduction}

The supplementation of trace elements plays an crucial role in maintaining optimal health and performance of livestock, though they are required in small amount (>100 mg/kg dry matter), but these minute amount is essential for maintaining antioxidant status and immune response of living organism. They are also useful for growth, production and reproduction of livestock. Trace elements are pivotal for proper functioning of numerous proteins and enzymes which contributes to the proper growth and production of animals (Yatoo et al., 2013). Supplementation of higher amount of trace element is not necessary, but the usable amount (more than the requirement) of trace elements for the animal is crucial.

Trace mineral (TM) form can also alter the absorption and metabolism, due to modifications in the chemistry of the supplemented form (Pino and Heinrich, 2016). Though, trace minerals have conventionally been supplemented in animal diets as inorganic salts (primarily sulphate and oxide forms), organic trace minerals (chelated or complexes to organic ligands) and nano form.

A challenge with organic and inorganic trace minerals is that they are hygroscopic and oxidative with other nutrients like fats and vitamins. Inorganic TM sources will irritate the intestinal mucosa, will also form complex with other nutrients and finally be expelled into the environment (Mwangi et al., 2017) thereby decreasing bioavailability of mineral. Studies (Sun et al., 2020) reported that organic form of trace mineral has higher bioavailability as compared with inorganic source, but its cost of production was higher as compared with inorganic source. Nano form has shown many advantages over organic and inorganic sources, but their wastage is more through dust due to its low particle size.

Recently hydroxy form represents a new form of trace mineral source that include copper, zinc and manganese. These are third generation trace mineral sources. The positive impact of hydroxy minerals in feed (better stability of feed ingredients) as well as in animals (higher bioavailability) have been already confirmed (Lu et al., 2010; Shaeffer et al., 2017). This form of trace minerals has also shown higher palatability as compared with inorganic source (Caramalac et al., 2017). These are approved by European Union as nutritional supplement for all animal species including the use in organic feeds. They have a crystalized structure where the metals are covalently bonded to multiple hydroxy groups and chloride group (Leisure et al., 2014) thus possesses high stability in premix and complete feed. They are non-hygroscopic, free of dust and are non-oxidative in nature; hence they have no impact on essential nutrients such as vitamins, fats, etc. Due to presence of covalent bond in crystalline structure, hydroxy trace elements are stable (insoluble) at higher $\mathrm{pH}$ of rumen $(\mathrm{pH}-6.8)$ as compared inorganic source (Caldera et al., 2019). These are more soluble at the lower $\mathrm{pH}$ (acidic medium) of the stomach and small intestine where it will be broken down and provides the essential mineral throughout GI tract, and will show higher absorption and bioavailability in ruminants (Shaeffer et al., 2017), pigs (Creech et al., 2004) and poultry as compared with inorganic sources.

\section{Chemistry of different sources of trace minerals}

There are different forms of trace minerals (TM) available in the market, and research has shown that these sources will not have same bioavailability.

Inorganic mineral source

Trace minerals that bound to groups like sulfates $\left(\mathrm{SO}_{4}\right)$, chlorides $(\mathrm{Cl})$ or oxides $(\mathrm{O})$ through ionic bond are known as Inorganic sources (Taylor and Field, 1995). Inorganic TM have been the primary option for feed grade TM supplementation for decades due to their affordability and high rumen solubility (Ammerman and Goodrich, 1983).

Organic mineral source

Organic trace minerals were formed by chelation. In chelation, the metal ion was bound strongly with organic molecules (ligands) through covalent bond to form a ring structure which defends the mineral element from entering into unwanted reactions. Organic mineral supplements are generally varied as per the type of ligand or ligands used to form the metal complex or chelate. Most of the organic minerals marketed as complexes, chelates or proteinates (Spears, 1996).

Nano mineral source

Nano minerals are formed by manipulation of particle with dimensions not more than a micron to that of individual atom. They are characterized by a particle size of 1 to $100 \mathrm{~nm}$. Some of these are stable at high temperature and pressure (Stoimenov et al., 2002) and they are easily assimilated in the digestive system (Feng et al., 2009). Due to larger surface area, this form of mineral will show better interaction with other biologically active substances under in vivo condition (Zaboli et al., 2013). Some nano components can bind and remove toxins and 
Reddy et al 2021/ J Livestock Sci. 12: 279-286

pathogens.

Hydroxy form

Recent advancement in mineral nutrition is the introduction of hydroxylated $\mathrm{Cu}, \mathrm{Mn}$ and $\mathrm{Zn}$ sources. A pure form of mineral that is reacted with alkali to form a hydrolysed inorganic metal complex was referred as hydroxy trace mineral. Here, the trace metal was covalently bonded to hydroxy groups and to chloride group. Hydroxy TM are considered inorganic, however, they are covalently bound to an $\mathrm{OH}$ group instead of the carbon containing ligands that seems like organic TM (Arthington, 2015). The $\mathrm{OH}$ group prevents the mineral from going into solution at the neutral $\mathrm{pH}$ range of the rumen $(\mathrm{pH}-6.8)$ and hydroxy-bound forms will get dissociated at a $\mathrm{pH}$ range of 1.6 to 2.5 , which closely mimics the $\mathrm{pH}$ of the abomasum and early portion of small intestine (Spears, 2003).

In livestock feed hydroxy form of trace minerals are provided in the forms of copper hydroxy chloride $\left.\left[\left(\mathrm{Cu}_{2} \mathrm{OH}\right)_{3} \mathrm{Cl}\right)\right]$, zinc hydroxy chloride $\left(\mathrm{Zn}_{5}(\mathrm{OH})_{8} \mathrm{Cl}_{2}\right)$ and manganese hydroxy chloride $\left(\mathrm{Mn}_{2}(\mathrm{OH})_{3} \mathrm{Cl}\right)$.

\section{Mode of action of hydroxy trace minerals}

\section{In ruminants}

In the rumen, multiple nutrient interactions can cause disturbance of the rumen function and reduce fermentation, which results in impaired performance. If the solubility was higher at neutral $\mathrm{pH}$, then these interactions may occur within the rumen. Soluble copper that's released within the rumen is very reactive and will lead to impaired efficacy of the microbiota, and will show negative impact on rumen health and production. Hydroxy forms of minerals are characterized with strong intramolecular bonds as compared with the weak bonds of inorganic minerals. Due to its fully defined crystalline structure, it is completely insoluble at rumenal $\mathrm{pH}$ and will by-pass the rumen (Genther and Hansen, 2015) and get absorbed at the acidic pH of small intestine. Supplementation of hydroxy $\mathrm{Zn}$ up to $160 \mathrm{ppm}$ did not show any adverse effect on in-vitro rumen fermentation parameters (Pal et al., 2020).

In monogastric animals

In monogastric animals, hydroxy form of trace minerals will show limited interaction with antagonists in the upper GI tract, thus the availability of trace minerals will be increased in the lower GI tract where they get absorbed and used for normal biological functions of the body. Whereas, the inorganic sources will react with other nutrients, minerals and causes antagonistic action in the upper GI tract, which makes the trace mineral unavailable for the body.

\section{Solubility}

The solubility of the minerals will vary depending on the source and the source which has high solubility in the rumen will get utilized by the rumen microbes. A form of copper that might not react with Mo and $\mathrm{S}$ in the rumen and thus, remain available for absorption would be desirable. Metal-hydroxy bound sources have shown lesser solubility in the $\mathrm{pH}$ of rumen. Hydroxy copper has very low solubility in the water as compared with $\mathrm{Cu}$ sulphate (Miles et al., 1998) and are more resistant to interactions with Mo and S in the rumen. This could result in copper from hydroxy copper being more available for absorption following solubilisation in the acid environment of the abomasum. Spears et al. (2004) stated that Copper from $\mathrm{Cu}$ sulphate have shown higher solubility in water and $0.1 \% \mathrm{HCl}$. Hydroxy form was almost totally insoluble in water. However, 767 and $868 \mathrm{~g} / \mathrm{kg}$ of Cu from hydroxy copper were soluble after incubation in $0.1 \% \mathrm{HCl}$ for 1 and $3 \mathrm{hr}$, respectively.

In a recent study, Genther and Hansen (2015) evaluated the solubility of hydroxy form of $\mathrm{Zn}, \mathrm{Cu}$ and $\mathrm{Mn}$ against sulphate forms in the rumen and abomasum. The 5 dietary treatments were as follows: control: no extra supplementation of copper, zinc and manganese; in another treatments, they have supplemented lower doses of copper, zinc and manganese from hydroxy and sulfate form; and higher doses of copper, zinc and manganese from hydroxy and sulfate forms. They observed that hydroxy copper and manganese have shown lesser solubility in rumen as compared with their sulfate counterparts. Under acidic conditions hydroxy $\mathrm{Cu}$ was equally as soluble as sulfate $\mathrm{Cu}$, hydroxy $\mathrm{Zn}$ had shown more solubility as sulfate $\mathrm{Zn}$ and hydroxy $\mathrm{Mn}$ was less soluble than sulfate $\mathrm{Mn}$.

Similarly, Caldera et al. (2019) had stated that Copper and Zinc from hydroxy trace mineral (HTM) have shown lower solubility in the rumen and appear to be less tightly bound to solid digesta in the rumen than Copper and Zinc from sulfate trace mineral (STM). Concentrations of zinc and copper in rumenal solid digesta increased with time up to $12 \mathrm{~h}$ post-dosing in steers given HTM. 


\section{Bioavailability of Hydroxy traces minerals}

Bioavailability determines efficacy of trace minerals. Bioavailability of a nutrient was defined as the portion of the ingested nutrients that get absorbed and will get utilized for normal physiological functions. Bioavailability of a mineral from any feed depends on its accessibility, absorbability, retainability and functionality (Suttle, 2010). An increase in bioavailability of copper hydroxychloride was observed as compared to copper sulfate when added to cattle diet high in copper antagonist, Mo and S. This could be due to lesser interaction of hydroxy copper with molybdenum and sulphur than copper sulphate in rumen because of low solubility at neutral $\mathrm{pH}$. However, bioavailability of hydroxy form of copper was similar to copper sulphate when evaluated in copper depleted cattle supplemented with diets low in molybdenum (Spears et al., 2004).

Similarly, Vanvalin et al. (2019) who observed an increase in relative bioavailability of hydroxy form of copper (112\%) compared with inorganic source ( set as 100\%) based on liver $\mathrm{Cu}$ concentrations suggesting that hydroxy form of copper be more efficiently absorbed and incorporated into liver $\mathrm{Cu}$ stores. Luo et al. (2005) studied the bioavailability of copper supplemented @ 0,150,300 and $450 \mathrm{mg} / \mathrm{kg}$ from sulfate or hydroxy form of copper in commercial broiler chicks. Result showed a slope ratio of $109.0 \%$ for bioavailability with copper from hydroxy form compared with 100 for that of copper sulfate. Similarly, in another experiment an increased copper concentration in egg yolk was observed in layers when supplemented with hydroxy copper than those supplemented with $\mathrm{CuSO}_{4}$ due to increased bioavailability of hydroxy copper (Kim et al., 2016).

Zhang and Guo (2007) had evaluated the bioavailability of zinc in hydroxy form in comparison to $\mathrm{ZnO}$ is estimated in weanling piglets. Based on plasma, liver, kidney and metacarpal zinc concentrations, relative bioavailability of zinc in hydroxy form was $159 \%, 125 \%$ and $128 \%, 123 \%, 122 \%$, respectively, as compared with $\mathrm{ZnO}$. Hydroxy form could be a desirable $\mathrm{Zn}$ source compared with $\mathrm{ZnO}$ for weanling piglet diets to enhance growth performance at lower dosage (1500 ppm) of hydroxy $\mathrm{Zn}$ as compared to $3000 \mathrm{ppm}$ of $\mathrm{ZnO}$. It may be due to increased bioavailability of hydroxy $\mathrm{Zn}$ compared to $\mathrm{ZnO}$. Similarly, Shaeffer et al. (2017) estimated the bioavailability of zinc in growing steers from two different sources i.e. $\mathrm{ZnOHCL}$ and $\mathrm{ZnSO}_{4}$. They supplemented 25 $\mathrm{mg} \mathrm{Zn} / \mathrm{kg} \mathrm{DM}$ from $\mathrm{ZnOHCl}$ and $\mathrm{ZnSO}_{4}$ to the growing steers and showed an increased $\mathrm{Zn}$ bioavailability in steers supplemented with ZnOHCL, which was reflected by higher plasma zinc concentrations. The inceased bioavailability of zinc from hydroxy form relative to $\mathrm{ZnSO}_{4}$ may be related with its lower solubility in rumen.

\section{Effect of Hydroxy trace minerals source on animals health and production}

\section{Effect on calves}

A young dairy calf faces many stress causing factors as they adopt to their environment. These stressors can affect all the normal physiological functions of body such as dry intake, growth, immunity etc. Trace elements will improve antioxidant status and immune responses of calves, so their supplementation was necessary in calves.

Lapierre (2016) conducted an experiment to evaluate differences in intake, growth, and health level of calves fed milk replacer (MR) and starter grain supplemented with sulfate and hydroxy form of TM. In MR either sulphate or hydroxy form of $\mathrm{Zn}, \mathrm{Cu}$, and $\mathrm{Mn}$ are supplemented at 50,10 , and $50 \mathrm{mg} / \mathrm{kg}$, respectively; starter grain either sulphate or hydroxy form of $\mathrm{Zn}, \mathrm{Cu}$ and $\mathrm{Mn}$ are supplemented at 70, 17, and $60 \mathrm{mg} / \mathrm{kg}$ respectively. They summarised that calves fed on hydroxy trace minerals supplemented in their milk replacer (MR) exhibit a propensity to consume more starter grain and increase their total dry matter intake. Moreover, calves consuming milk replacer supplemented with hydroxy trace minerals were taller at the end of the trial and showed a significant reduction in scours and the amount of medication used. Whole plasma concentration of zinc was higher in calves consuming HTM treated milk replacer. Finally, supplementation of hydroxy form of trace minerals will enhance a healthier calf that is able to utilize nutrients for their growth.

\section{Effect on lactating animals}

The specific roles of trace minerals have received substantial attention in dairy cows and few works have been conducted to estimate the effects of different trace mineral sources on its productive and reproductive performance. Yasui et al. (2014) studied the effects of hydroxy form of trace minerals on oxidative metabolism, performance and cytological endometritis of transition dairy cows. Dietary treatments supplemented with daily topdressing includes (1) inorganic sulphate forms of $\mathrm{Zn}, \mathrm{Cu}$, and $\mathrm{Mn}$ (ITM) (2) $\mathrm{Zn}, \mathrm{Cu}$, and $\mathrm{Mn}$ through sulphates and organic complexes in the ratio of 75:25 (ITM/OTM) and (3) hydroxy form of $\mathrm{Zn}, \mathrm{Cu}$, and Mn (HTM). They summarised that cattle fed HTM throughout the prepartum period have shown increased body weight (BW) than those fed ITM. Furthermore, Plasma total antioxidant capacity was declined in the cows supplemented with HTM than ITM but, it was not different in the cows fed ITM/OTM. Cattle fed HTM tend to have lower concentrations of 
plasma TBARS than those fed ITM throughout the study period.

Faulkner and Wiess (2017) conducted a study to see effect of trace mineral sources in either forage- or byproduct-based diets supplemented to dairy cows. They observed that digestibility of fiber and milk fatty acid profiles have differed when animals were supplemented with hydroxy or sulfate form of trace minerals. Increased neutral detergent fiber digestion will recommend that hydroxy mineral supplementation is helpful for cellulolytic bacteria would be due to negative effect of sulfate source on fibrolytic bacteria. Similarly, Miller et al. (2020) had observed that cows fed the hydroxy trace mineral (HTM) diets had greater DMI than cows fed the sulphate form (STM) diets. This difference in DMI between the HTM and STM diets can be partially accounted for by the difference in totaltract digestibility of aNDFom.

\section{Effect on steers}

Recently many works have been conducted to estimate the effects of different trace mineral sources on animal's carcass quality. Wagner et al. (2016) conducted an experiment on yearling steers to corelate the effects of mineral sources at 2 different concentrations. The treatments included are control $(90 \mathrm{mg} / \mathrm{kg}$ of $\mathrm{Zn}$ through $\mathrm{Zn}$ sulphate and $15 \mathrm{mg} / \mathrm{kg}$ of $\mathrm{Cu}$ from $\mathrm{Cu}$ sulphate); organic (org) $(67.5 \mathrm{mg} / \mathrm{kg}$ of $\mathrm{Zn}$ through $\mathrm{Zn}$ sulphate plus 22.5 $\mathrm{mg} / \mathrm{kg}$ of $\mathrm{Zn}$ through $\mathrm{Zn}$ amino acid complex and $11.25 \mathrm{mg} / \mathrm{kg}$ of $\mathrm{Cu}$ from Cu sulphate plus $3.75 \mathrm{mg} / \mathrm{kg}$ of Cu from $\mathrm{Cu}$ amino acid complex); high dose of hydroxy form (IB100) (90 mg/kg of Zn through Zn hydroxychloride and 15 $\mathrm{mg} / \mathrm{kg}$ of $\mathrm{Cu}$ from basic $\mathrm{Cu}$ chloride) and low dose of hydroxy form (IB60) (54 mg/kg of Zn through $\mathrm{Zn}$ hydroxychloride and $9 \mathrm{mg} / \mathrm{kg}$ of $\mathrm{Cu}$ from $\mathrm{Cu}$ hydroxy chloride). They summarised that hydroxy form of $\mathrm{Cu}$ and $\mathrm{Zn}$ are effectively absorbed and utilized by yearling steers and can be fed at a lower dose as compared with current industry feeding practices without negative effects on growth performance, carcass traits and liver $\mathrm{Zn}$ and $\mathrm{Cu}$ status.

\section{Effect on layers}

Oluyinka et al. (2019) had studied the effect of sulfate and hydroxy form of trace minerals ( $\mathrm{Zn}, \mathrm{Cu}$ and $\mathrm{Mn}$ ) in the laying hens and observed that $\mathrm{Mn}, \mathrm{Zn}$ and $\mathrm{Cu}$ hydroxychloride had reduced the egg loss by reducing the percentage of cracked eggs and has increased yolk trace mineral concentration when compared with sulphate form, even though their effect on egg production was minimal in hens at peak production.

Similarly, Toghyani et al. (2019) had conducted an experiment to estimate the effect of replacing inorganic sources with Hydroxychloride sources on egg production, egg quality parameters and feed stability in layer diet during post-peak production. Inclusion of hydroxychloride $\mathrm{Zn}, \mathrm{Cu}$ and $\mathrm{Mn}$ reduces the extent of oxidation in the feed, as indicated by lower peroxide ( 0.7 vs. $1.5 \mathrm{mEq} / \mathrm{kg})$, higher free fatty acids $(0.95 \mathrm{vs} .0 .78 \% \mathrm{w} / \mathrm{w})$ and higher iodine values ( 4.0 vs. $3.0 \mathrm{~g} / 100 \mathrm{~g}$ ) measured in the feed samples as compared to inorganic form. Shell reflectivity percentage was also improved by $1.1 \%$ in the hydroxychloride treatment. They summarised that using hydroxychloride source of $\mathrm{Cu}, \mathrm{Zn}$ and $\mathrm{Mn}$ in layer diets will improve feed stability, egg production rate and FCR.

\section{Effect on broilers}

Super oxide dismutase (SOD) was a metalloenzyme with copper, zinc and manganese as a cofactor. MnSOD is found primarily in the matrix space of mitochondria, whereas the $\mathrm{Cu}$ and $\mathrm{Zn}$-SOD were found in the intermembrane space. Trace minerals are vitally important in supporting bone and tissue development as well as for maintenance of the immune system in broilers. Perez et al. (2017) have done two experiments to estimate the effect of hydroxy and sulphate form of $\mathrm{Zn}$ and $\mathrm{Mn}$ supplementation on broiler bird immune response post LPS injection. They reported that broilers fed with diets which have lower amounts of zinc and manganese in sulphate form had shown lower SOD activity and IL-1 and cathelicidin amounts during inflammation and by supplementing zinc and manganese in $\mathrm{OHCl}$ form showed an increase in the SOD activity and IL-1 and cathelicidin mRNA amounts in the immune cells. Lower concentrations of hydroxy and organic forms of minerals in broiler diets have been recommended as a solution to reduce the excretion of mineral without any objectionable effect on performance. Similarly, Broilers fed organic $(\mathrm{O})$ and hydroxy $(\mathrm{H})$ minerals have shown higher weight gain and lower FCR as compared with the inorganic (I) treatment. Thus, they had finalized that lower dosage of minerals as hydroxychlorides may offer performance and economic profits over sulphates or oxides form (M'Sadeq et al., 2018).

Oluyinka et al. (2018) studied the influence of hydroxychloride form of minerals on growth performance, carcass yield and tissue trace mineral content of broilers as compared to inorganic source. Broilers chicks were allocated 4 dietary treatments i.e. high sulphate, low sulphate, high hydroxychloride and low hydroxychloride forms of $\mathrm{Zn}$ and stable amount of $\mathrm{Cu}$ in all the treatments. They observed that broiler chicken supplemented with $\mathrm{Zn}$ hydroxychloride with low level had greater feed efficiency, percent breast yield and greater weight gain than sulphate source. Liver $\mathrm{Cu}$ concentration was higher in broiler chickens receiving hydroxy form of $\mathrm{Zn}$ and $\mathrm{Cu}$. They 
summarised that hydroxychlorides were more effective than sulfate sources in enhancing growth performance and promoting meat yield in broilers.

Similarly, Oluyinka et al. (2019) observed superior weight gain in broiler chickens supplemented with hydroxychloride trace mineral as compared to those receiving sulphate trace minerals. The level of supplementation of $\mathrm{Cu}, \mathrm{Zn}$ and $\mathrm{Mn}$ are 15, 80, and $80 \mathrm{ppm}$ respectively for both sulphate and hydroxychloride minerals. Greater feed intake in the broilers receiving hydroxychloride TM will be due to greater intake of the TM. Thus, they have summarised that broilers receiving hydroxychloride trace mineral have improved growth performance.

In plasma, the levels of methyl malonic and uric acid are low in broiler chickens supplemented with hydroxy form of $\mathrm{Zn}$ and $\mathrm{Cu}$. This will suggest that this trace mineral source will support a more robust tolerance to oxidative stress. Hence, broilers receiving hydroxy trace mineral have greater resistance to oxidative stress (Oluyinka et al., 2019).

\section{Effect on pigs}

Recently many studies have been carried on to estimate the effect of different of trace minerals sources on performance and immune response in pigs. Carpenter et al. (2016) studied the effects of zinc trace mineral sources carcass characteristics of finishing pig and observed that pigs supplemented with Zn hydroxychloride (100 ppm) had heavier hot carcass weight (HCW) and increased hot carcass weight average daily gain (HCW ADG) than those fed $\mathrm{ZnSO}_{4}$. They suggested that little overall differences between $\mathrm{Zn}$ sources on growth performance; however, pigs supplemented diets with $\mathrm{Zn}$ hydroxychloride had greater $\mathrm{HCW}$ as compared with sows that fed with $\mathrm{ZnSO}_{4}$.

Similarly, Lu (2018) reported that sows fed hydroxy copper diets had higher adjusted litter and piglet weight gain when compared to sows that have offered $\mathrm{CuSO}_{4}$ diets. Also, milk of sows that have fed with hydroxy copper $(\mathrm{CuOHCl})$ diets had an increased concentration of protein than that from sows fed $\mathrm{CuSO}_{4}$ diets. Lactating sows fed hydroxy copper diets had an improved activity of $\mathrm{Cu} / \mathrm{Zn}$ superoxide dismutase (SOD) and ceruloplasmin in serum than those fed $\mathrm{CuSO}_{4}$ diets. The hydroxy copper may be a superior $\mathrm{Cu}$ source compared to $\mathrm{CuSO}_{4}$ regarding reproductive performance, and elevated dietary $\mathrm{Cu}$ levels result in eminent birth weight of piglets; furthermore, high $\mathrm{Cu}$ levels in sow and nursery diets promote growth performance of nursery pigs and also helpful in maintaining immune response during lactation period.

Recently, Vankuijk et al. (2019) conducted a meta-analysis in pigs to assess the effect of HTM source and ITM source $(80 \mathrm{ppm})$ on growth performance of pig. During their study period, there was an increased FCR in pigs which have been fed with $80 \mathrm{ppm}$ Zn from HTM. In the last feeding phase, before slaughter FCR and average daily gain were both significantly enhanced by $3.9 \%$. HTM addition had enhanced growth performance in grower-finisher pigs.

\section{Economic importance}

The cost of production of trace mineral source is also a major comparable aspect. The negative aspect regarding organic source was its high cost of production. Elemental $\mathrm{Zn}$ and $\mathrm{Cu}$ costs calculated from their prices and the concentration of elemental $\mathrm{Zn}$ or $\mathrm{Cu}$ in each source were $\$ 3.82 / \mathrm{kg}$ of $\mathrm{Zn}, \$ 10.48 / \mathrm{kg}$ of Cu, $\$ 32.14 / \mathrm{kg}$ of $\mathrm{Zn}$, $\$ 52.90 / \mathrm{kg}$ of $\mathrm{Cu}, \$ 11.14 / \mathrm{kg}$ of $\mathrm{Zn}$, and $\$ 15.20 / \mathrm{kg}$ of $\mathrm{Cu}$ for $\mathrm{Zn}$ sulfate, $\mathrm{Cu}$ sulfate, $\mathrm{Zn}$ amino acid complex, $\mathrm{Cu}$ amino acid complex, $\mathrm{Zn}$ hydroxychloride, and basic $\mathrm{Cu}$ chloride, respectively. In comparison between the cost of different trace mineral sources, Hydroxy form of minerals is far cheaper than organic forms and is more or less equal to the inorganic source of minerals (Wagner et al., 2016).

\section{Conclusion}

Based on above the mentioned works in livestock including poultry in which they have proved that the hydroxy form of trace mineral is helpful in improving the immune response as well as productive and reproductive performance in the animals and will also offer economic benefits over organic and inorganic sources. Thus, we can say that hydroxy form of trace mineral is the best replacement for the older form of trace minerals for maximizing health and production of animals. 


\section{References}

1) Ammerman CB, Goodrich R, 1983. Advances in mineral nutrition in ruminants. Journal of Animal Science 57: 519-533.

2) Arthington JD, 2015. New concepts in trace mineral supplementation of grazing cattle hydroxy sources, injectable sources and pasture application. In: 26th Annual Florida Ruminant Nutrition Symposium, Florida, 2-4, February 2015, Department of Animal Sciences, pp 104-117.

3) Bhalakiya N, Haque N, Patel P, Joshi P, 2019. Role of Trace Minerals in Animal Production and Reproduction. International Journal of Livestock Research 9(9): 1-12.

4) Caldera E, Weigel B, Kucharczyk VN, Sellins KS, Archibeque SL, Wagner JL, Han H, Spears JW, Engle TE, 2019. Trace mineral source influences ruminal distribution of copper and zinc and their binding strength to ruminal digesta. Journal of Animal Science 97: 1852- 1864.

5) Caramalac LS, Netto AS, Martins PGMA, Moriel P, Ranches J, Fernandes HJ, Arthington JD, 2017. Effects of hydroxychloride sources of copper, zinc, and manganese on measures of supplement intake, mineral status, and pre-and postweaning performance of beef calves. Journal of Animal Science 95(4): 1739-1750.

6) Carpenter C, Coble K, Woodworth JC, DeRouchey JM, Tokach MD, Goodband RD, Usry J, 2016. Effects of increasing $\mathrm{Zn}$ from zinc sulfate or zinc hydroxychloride on finishing pig growth performance, carcass characteristics, and economic return. Kansas Agri Exp Sta Res Rep 2(8): 39.

7) Creech BL, Spears JW, Flowers WL, Hill GM, Lloyd KE, Armstrong TA, Engle TE, 2004. Effect of dietary trace mineral concentration and source (inorganic vs. chelated) on performance, mineral status, and fecal mineral excretion in pigs from weaning through finishing. Journal of Animal Science 82(7): 2140-2147.

8) Faulkner MJ, Weiss WP, 2017. Effect of source of trace minerals in either forage or by- product based diets fed to dairy cows: Production and Macronutrient digestability. Journal of Dairy Science 100(7): 5358 - 5367.

9) Feng M, Wang ZS, Zhou AG, Ai DW, 2009. The eff ects of diff erent sizes of nanometer zinc oxide on the proliferation and cell integrity of mice duodenum-epithelial cells in primary culture. Pakistan Journal of Nutrition 8(8): 1164-1166.

10) Genther ON, Hansen SL, 2015. The effect of trace mineral source and concentration on ruminal digestion and mineral solubility. Journal of Dairy Science 98(1): 566-573.

11) Kim JW, Kim JH, Shin JE, Kil DY, 2016. Relative bioavailability of copper in tribasic copper chloride to copper in copper sulphate for laying hens based on egg yolk and feather copper concentrations. Poultry Science 95(7): 1591-1597.

12) Lapierre PA, 2016. Effects of Hydroxy versus sulfate forms of trace minerals in milk replacer or starter on dairy calves through weaning. Doctoral Dissertation (Animal Sciences), University of Illinois at Urbana, Champaign.

13) Leisure NJ, Jackson CC, Huang M, Moore TB, Steward FA, 2014. Micronutrient supplement, U.S. Patent No. $8,802,180$. Washington, DC: U.S. Patent and Trademark Office.

14) Lu L, Wang RL, Zhang ZJ, Steward FA, Luo X, Liu B, 2010. Effect of dietary supplementation with copper sulfate or tribasic copper chloride on the growth performance, liver copper concentrations of broilers fed in floor pens, and stabilities of vitamin E and phytase in feeds. Biological Trace Element Research 138(1-3): 181-189.

15) Lu N, 2018. Long- term effects of dietary copper source and level on performance and health of sows and piglets. Theses and Dissertations (Animal and Food Sciences). College of Agriculture, Food and Environment, University of Kentucky, Lexington.

16) Luo XG, Ji F, Lin YX, Steward FA, Lu L, Liu B, Yu SX, 2005. Effect of dietary supplementation with copper sulfate or tribasic copper chloride on broiler performance, relative copper bioavailability and oxidative stability of vitamin E in feed. Poultry Science Association 84(6): 888- 893.

17) M'Sadeq SA, Wu SB, Choct M, Swick RA, 2018. Influence of trace mineral sources on broiler performance, lymphoid organ weights, apparent digestibility, and bone mineralization. Poultry Science 97(9): 31763182.

18) Miles RD, O'Keefe SF, Henry PR, Ammerman CB, Luo XG, 1998. The effect of dietary supplementation with copper sulfate or tribasic copper chloride on broiler performance, relative copper bioavailability and dietary prooxidant activity. Poultry Science 77(3): 416-425.

19) Miller MD, Lanier JS, Kvidera SK, Dann HM, Ballard CS, Grant RJ, 2020. Evaluation of source of corn silage and trace minerals on lactational performance and total-tract nutrient digestibility in Holstein cows. Journal of Dairy Science 103:3147-3160. 
20) Mwangi S, Timmons J, Ao T, Paul M, Macalintal L, Pescatore A, Cantor A, Ford M, Dawson KA, 2017. Effect of zinc imprinting and replacing inorganic zinc with organic zinc on early performance of broiler chicks. Poultry Science 96(4): 861-868.

21) NRC, 2012. Nutrient requirements of swine. National Academies Press, Washington, DC.

22) Oluyinka AO, Van Kuijk S, Han Y, 2018. Copper and zinc sources and levels of zinc inclusion influence growth performance, tissue trace mineral content, and carcass yield of broiler chickens. Poultry Science 97(11): 3891- 3898.

23) Oluyinka AO, Van Kuijk SJ, Han Y, 2019. Sulfate and hydroxychloride trace minerals in poultry diets comparative effects on egg production and quality in laying hens, and growth performance and oxidative stress response in broilers. Poultry Science 98(10): 4961-4971.

24) Pal RP, Mani V, Sarkar S, Mir SH, Sharma A, 2020. Comparing the effect of different levels of zinc hydroxychloride with inorganic zinc sulfate on in vitro rumen fermentation parameters. Indian Journal of Dairy Science 73(6): 1-7.

25) Perez V, Shanmugasundaram R, Sifri M, Parr TM, Selvaraj RK, 2017. Effects of hydroxychloride and sulfate form of zinc and manganese supplementation on superoxide dismutase activity and immune responses post lipopolysaccharide challenge in poultry fed marginally lower doses of zinc and manganese. Poultry Science 96(12): 4200-4207.

26) Pino F, Heinrichs AJ, 2016. Effect of trace minerals and starch on digestibility and rumen fermentation in diets for dairy heifers. Journal of Dairy Science 99(4): 2797-2810.

27) Shaeffer GL, Lloyd KE, Spears JW, 2017. Bioavailability of Zinc hydroxychloride relative to zinc sulfate in growing cattle fed a corn -cottonseed hull- based diet. Animal Feed Science and Technology 232: 1-5.

28) Spears JW, 1996. Organic trace minerals in ruminant nutrition. Animal Feed Science Technology 58(1-2):151163.

29) Spears JW, 2003. Trace mineral bioavailability in ruminants. The Journal of Nutrition 133(5): 1506-1509.

30) Spears JW, Kegley EB, Mullis LA, 2004. Bioavailability of copper from tribasic copper chloride and copper sulfate in growing cattle. Animal Feed Science and Technology 116(1-2): 1-13.

31) Stoimenov PK, Klinger RL, Marchin GL, Klabunde KJ, 2002. Metal oxide nanoparticles as bactericidal agents. Langmuir 18(17): 6679-6686.

32) Sun W, Wang G, Pei X, Liu L, Xiao Z, Tao W, Pelletier W, 2020. Effects of Replacing Inorganic with Respective Complexed Glycinate Minerals on Apparent Mineral Bioavailability and Deposition Rate in Tissues of Broiler Breeders. Biological Trace Element Research 1-7.

33) Suttle NF, 2010. Mineral Nutrition of Livestock. 4th ed. CABI Publ., Wallingford, Oxfordshire, UK.

34) Taylor RE, Fields TG, 1995. Scientific Farm Animal Production. 6th. ed. Prentice Hall. Upper Saddle River, NJ.

35) Toghyani M, Nguyen TTH, Morgan NK, Wu SB, Swick RA, 2019. Laying performance, egg quality and feed stability in response to replacement of inorganic zinc, copper and manganese with hydroxychloride sources in Hy-line layer hen's diet. In: 30th Annual Australian Poultry Science Symposium, Sydney, 1720, February 2019, The Pou Res Ass, pp 70.

36) Vankuijk SJ, Jacobs M, Smits CH, Han Y, 2019. The effect of hydroxychloride trace minerals on the growth performance and carcass quality of grower/finisher pigs: a meta-analysis. Journal of Animal Science 97(11): 4619-4624.

37) Vanvalin KR, Genther ON, Laudert SB, Hansen SL, 2019. Relative bioavailability of organic and hydroxy copper sources in growing steers fed a high antagonist diet. Journal of Animal Science 97(3): 1375- 1383.

38) Wagner JJ, Engle TE, Caldera E, Neuhold KL, Woerner DR, Spears JW, Heldt JS, Laudert SB, 2016. The effect of zinc hydroxychloride and basic copper chloride on growth performance, carcass charecteristics, and liver zinc and copper status at slaughter in yearling feedlot steers. The Proffessional Animal Scientist 32(5): 570- 579.

39) Yasui T, Ryan CM, Gilbert RO, Perryman KR, Overton TR, 2014. Effect of hydroxy trace minerals on oxidative metabolism, cytological endometritis, and performance of transition dairy cows. Journal of Dairy Science 97(6): 3728- 3738.

40) Yatoo MI, Saxena A, Deepa PM, Habeab BP, Devi S, Jatav RS, Dimri U, 2013. Role of trace elements in animals: a review. Veterinary World 6(12): 963.

41) Zaboli K, Aliarabi H, Bahari AA, Abbas AKR, 2013. Role of dietary nano-zinc oxide on growth, performance and blood levels of mineral: a study on Iranian Angora (markhoz) goat kids. International Advisory Board 2: 19-26.

42) Zhang B, Gou Y, 2007. Beneficial effects of tetrabasic zinc chloride for weanling piglets and bioavailability of zinc in tetrabasic form relative to $\mathrm{ZnO}$. Animal Feed Science and Technology 135(1-2): 75-85. 